\title{
Institute Quality Improvement Through Management Training of Accreditation Preparation in TK Aisyiyah Bustanul Athfal Padang
}

\author{
Rosniati Hakim ${ }^{1}$, Khadijah $^{2}$, Mahyudin Ritonga ${ }^{3}$, Weti Susanti ${ }^{4}$, and Rahmi ${ }^{5}$ \\ ${ }^{1}$ Lecturer at Tarbiyah and Teaching Faculty, UIN Imam Bonjol, Padang, Indonesia \\ rosniatihakim@uinib.ac.id, rosniati_hakim@yahoo.com \\ ${ }^{2}$ Lecturer at Tarbiyah and Teaching Faculty, UIN Imam Bonjol, Padang, Indonesia \\ ${ }^{3}$ Lecturer, UMSB, Padang, Indonesia, mahyudinritonga@gmail.com \\ ${ }^{4}$ Lecturer, STAI YASTIS, Padang, Indonesia \\ ${ }^{5}$ Lecturer, UMSB, Padang, Indonesia
}

\begin{abstract}
The weakness of the role and existence of the Kindergarten 'Aisyiyah Bustanul RA as a basic institution of Islam that introduces and teaches the teachings of Islam for young children, due lack of fully professional management and generally have not been accredited. This will result in a weak child education and religious life, and reduced public confidence religious education and religious value internalization of very influential in self-learners. Overcoming this will require in-depth search of the problems, needs, and characteristics of each such institution as well as the solution that TK ABA Padang can be accredited well, achieving quality and good quality is legally recognized. Delivering solutions, especially in the charging instrument towards accreditation with Stakeholders who are competent in their field. Conducted through observation and transect walks/visits, in-depth interviews, focus group discussions, and formulate the problem of institutions. How to create quality improvement through management training institutions charging instrument preparation TK ABA Padang to accreditation? In this case the necessary action; mapping problems and needs, determine priorities for action management training, identifying potential, setting the whole manager TK ABA became a trainee, set the program, the type of exercise that comes from the manager TK ABA. The goal, the manager of $\mathrm{TK} \mathrm{ABA}$ is expected to be able to prepare and carry out accreditation.
\end{abstract}

Keywords: Management, Accreditation, Institute, Kindergarten.

\section{INTRODUCTION}

1. Background (Issues and Focus)

Islamic education in Indonesia is said to be the legacy of civilization, and even an asset for development of national education (Rosniati Judge: 2016). As a legacy, it was like a trustful history education should be maintained and developed by Muslims on an ongoing basis from time to time. Being an asset, Islamic education must be organized and managed according to the national education system. (Husni Rahim, 2001: 3). The success of an organization in achieving its objectives can not be separated from how its management and support of all parties. Each party or the element has its own function in achieving educational goals and will work when the manager or head as the leading executor is able to manage and exploit it (Surachmad; 1982: 45). Bustanul RA (BA) is one form of early childhood education units in formal education who conduct educational programs with the peculiarities of Islam for children ages 4 to 6 years (PMA No. 60 in 2015 on education Madrasah),Bustanul basic
Islamic education or RA (BA) as the most basic educational institution has a very important role in human development in Indonesia. Therefore, students should be prepared as well as possible, both socially and institutionally and functionally academic. Basuni Aziz, in the book "The view 15 People Private Education" (1993: 6) states that efforts to produce capable human beings, capable and professional, should start from the lowest level of education.

Kindergarten (TK) in the city of Padang is under the auspices of the Department of Education and the Ministry of Religion is quite a lot, both TK and TK ABA Raudhatul RA (TKRA), and other kindergarten. According to Mrs. Reny yudhia (Kasi early childhood Padang, 03,102,016, in the city of Padang Office of Education); the number of kindergartens under the Department of Education there are 275 units of Padang. 2015 new accredited TK 19 units, including two units of which TK ABA. 2016 is currently in the process of existing TK +100 units will drop its accreditation. 
Based on data from the Ministry of Religious EMIS Padang in 2015 found that the number of Raudhatul Athfal in Padang 39 units, with 175 teachers and 1865 children. (Fitria, Madrasah Education Ministry of Religious Affairs Padang City, May 18, 2016). While TKA Bustanul RA, totaling 31 units with 124 teachers and 1,141 children + . Of the 31 units of the new accredited B 2 units, meaning 29 more units have not been accredited. (Board; Herlina, the Association of Teachers' Aisyiyah Bustanul RA (IGABA), in the secretariat IGABA, 03,102,016)

The number of kindergartens in the city of Padang, which has not been accredited or accredited ranks not as expected. This is partly caused by TK problems do not have good management in preparing accreditation and does not have the knowledge, understanding and skills in preparing and filling accreditation forms / instruments in accordance with established standards. This is what makes TK in Padang accreditation is still far from satisfactory even largely not been accredited. Based on data from the Education madrasah (Fitria: May 18, 2016), obtained information that on 39 TKRA in Padang were already accredited 14 kindergartens (29\%) (accredited new 1 TKRA, Accreditation $\mathrm{B}=9$ units and $\mathrm{C}=4$ units). That is, there are $25(71 \%)$ who have not been accredited kindergarten. Guidance in the form of guidance or training to fill the accreditation forms / instrument accreditation has not been done by the relevant agencies, said Fitri. (Head of Madrasah Education/Ministry of Religious Affairs Pemad Padang). Likewise with TK ABA, from 31 units, accredited B, only two units (15\%), and have not been accredited 29 units (85\%). Medium coaching Padang City Department of Education has been done, but that only included 5 headmasters of 124 TK (Herlina said).

Conditions worsened with the institution's management is still far below the standard of management of educational institutions. Governing body (foundation) is still overlapping with the educator or educational staff in schools, foundations that are not designated in a professional manner, financial institutions are managed independently/private, teacher or teaching is not considered morally and materially, excluded from society in funding agencies, and so make TK faint of things like management, administration, infrastructure, quality of learning. In fact there are few TK makes daycare when the place for it was not available so the kindergarten classrooms are used. These conditions are increasingly making the learning process of students kindergarten disturbed.

Weak school management so that the accreditation process is inhibited or do not yet have an impact on student achievement of learning goals in kindergarten, also have an impact on public confidence in the basic level of religious educational institutions such as kindergartens wane. Interests of parents sending their children to kindergarten will also be less. The impact on the child is not good religious, meaning children as early as possible should be introduced and taught the doctrines and practice of religion, if they do not get an education at the basic level of religious educational institutions so they will not get religious instruction as early as possible.
The cause of the weakness of the institution's management, accreditation preparation, and charging accreditation forms are: first, HR (managers, education, and educators RA) is very weak. Second, the frequent change of school administrators, teachers and education personnel TK makes the management and administration of the school to be weak, because the management and administration of the school has always changed to change. Third, not maximal training and management development for kindergarten prep school accreditation, especially management and charging instrument. Fourth, limited funds, infrastructure, and tools to make accreditation preparation and filling of accreditation forms/instruments.

Based on the problems revealed and the impact that occurs when TK Padang are not preparing for the accreditation and has the ability to fill accreditation forms/instruments, needs to be resolved in order for kindergarten Padang can be accredited properly, so that the quality and legally recognized good quality. The positive impact of this service are: first, TK Padang accredited as a whole. Second, an increase in the quality and the quality of kindergarten legally. Third, the management and administration of kindergarten can run well. Fourth, the increasing level of public trust in particular religious educational institutions TK ABA, so that people want to put their children to attend kindergarten ABA. Fifth, it would be an increase in income and economic ABA kindergarten teacher, for kindergarten teacher salary Padang ABA average of student fees. Sixth, with the number of school revenue it will have an impact on the completeness and availability of facilities, infrastructure, and media learning so that learning objectives can be achieved with good. While the negative impact if the solution is not done, the weakening of the role and existence of TK ABA as the basic institution of Islam that introduce and teach the teachings of Islam for young children. This will result in a weak child education and religious life and will decrease in public confidence in the institutions and religious education due to the management who are not professional and is not accredited. weakening the role and existence of TK ABA as the basic institution of Islam that introduce and teach the teachings of Islam for young children. This will result in a weak child education and religious life and will decrease in public confidence in the institutions and religious education due to the management who are not professional and is not accredited. weakening the role and existence of TK ABA as the basic institution of Islam that introduce and teach the teachings of Islam for young children. This will result in a weak child education and religious life and will decrease in public confidence in the institutions and religious education due to the management who are not professional and is not accredited.

The reasons for selecting this ABA TK subject to notice things as follows: Initial survey results showed and concluded that tackling poor management and the preparation of accreditation and charging instruments is constrained, so it will need in-depth search of the problems, needs, and characteristics of each institution. 
a. Given the public demands quality kindergarten views of accreditation is very urgent to do.

b. Weak in the management and administration of the institution, then the manager of TK ABA does not have the knowledge and experience of how the accreditation preparation and questionnaire fulfillment / instrument accreditation.

c. $\quad \mathrm{TK} \mathrm{ABA}$ as a basic religious education institution which is a school that introduces the learning process, the formation of character, and the introduction of religious values in children. Therefore, TK ABA must be qualified institutions.

d. TK ABA as an educational institution that is mostly owned by the community, it is necessary for their development of universities such as the Faculty of MT and Teaching [FTK] UIN IB in improving the quality of independent institutions.

e. Establishment of cooperation between FTK with TK, so FTK ahead can open PGTK study programs, so that teachers in kindergarten can have a professional qualification of teachers according to their fields.

The problem is how to realize improvement of the quality of institutions through training preparation management kindergarten charging instrument 'Aisyiyah Bustanul Athfal Padang to accreditation? This problem will be addressed through the following actions.

a. Mapping the problems and needs

b. Determine priorities for action charging instrument management training accreditation preparation,

c. Identifying potential in order to determine what efforts have been made by TK ABA in school management in preparation for accreditation and charging questionnaire / instrument

d. Setting the whole manager TK ABA in Padang became a trainee

e. Assign the program, the type of exercise that comes from the manager TK ABA

\section{Significance}

One of the main tasks and functions of the National Accreditation Board for Non-Formal Education (BANPNF) is carrying out the accreditation of Early Childhood Education (ECD). Accreditation is a feasibility assessment activities and their units PNF program based on the established criteria. To assess the feasibility of structured instruments accreditation refers to the National Education Standards (NES) as determined by the Indonesian Government Regulation No. 32 of 2013 on the Amendment to the Indonesian Government Regulation No. 19 of 2005, which includes eight (8) standard, namely; a. Competency standards, b. Standard Contents, c. Standard Process, d. Standards and Education Personnel, e. Infrastructure Standards, f. Standard Management, g. Financing and $\mathrm{h}$ standards. Education Assessment Standards.

Special early childhood, Graduate Competency Standards uses the term Standard Achievement Rate Developments (TPP). Accreditation instrument used to obtain the data relating to eight (8) SNP that describes the objective conditions of early childhood. Therefore, these instruments must be filled by the manager early childhood or parties responsible for the implementation of early childhood. The answer to the question or statement must be in accordance with the procedure established early childhood accreditation by BAN-PNF. [Http://paudjateng.xahzgs.com./2016/02/downnloadinstrumen-akreditasi-paud-terbaru.Html / 01,112,016]

TK ABA accreditation is very important, given the purpose and benefits of the intended accreditation. In general, PNF Accreditation aims to provide an assessment (assessment) in an objective, transparent, and sustainable access to the feasibility of a program and PNF based on criteria that have been set. Implementation of the accreditation of the program and PNF will benefit, among others:

a. Improve the vision, mission, goals, objectives, strategies, programs and PNF;

b. Improving the quality of programs and PNF;

c. utilize all the information on the results of accreditation as feedback, in an effort to empower and develop the performance of the program and PNF;

d. PNF to encourage efforts to improve the quality of programs and institutions gradually, planned, and competitive at the district / city, provincial, regional, national, and even international;

e. Obtaining reliable and accurate information, in order to gain support non-formal learning society in the form of guidance from the Government of Pakistan and appreciation from the public. [http://web.banpnf.or.id/index.php/akreditasipnf/2014-06-27-09-02-23, Downloaded; 13102016]

Thus the importance of accreditation for an institution ABA kindergarten in the city of Padang, the necessary provision of solutions, especially in the charging instrument towards accreditation with Stakeholders who are competent in their field, as follows:

a. Padang City Department of Education as the competent institutions in fostering kindergarten in the city of Padang. In this activity Padang City Department of Education will assist in providing direction and information regarding the policies and rules of accreditation kindergarten.

b. FTK UIN IB, in this case a team of researchers / stewards and some other professors in science relating to the accreditation kindergarten. Lecturers involved are the instructors PLPG TK field, and also has experience in the organization and management of kindergartens. The lecturers involved also led courses that are experienced in the preparation of accreditation and charging accreditation forms / instruments.

c. Supervisory kindergarten, in this case the supervisor will provide guidance for the provision of the material with respect to the management and administration of kindergarten, thus simplifying the process of accreditation 
preparation and filling of accreditation forms / instruments.

d. Kindergarten Accreditation Assessor provincial assessor team involved in this training is not visitate assessor team kindergarten in the city of Padang, because the team worked closely with educational institutions assessor team of West Sumatra. Their involvement is to provide materials about the strategies and methods are effective and efficient in preparing for accreditation and charging accreditation forms / instruments.

3. strategy Implementation

a. Map the institution based on problems, needs, potentials, opportunities to kindergarten Padang.

b. Act in accordance with the problems and solutions that have been agreed.

c. Discussion of the results that have been achieved.

d. Discussion on the achievement of the activities and plans of action as an effort to target more

e. Exercise charging of programs that have been carried out with the involvement of institutions and stakeholders.

f. Evaluation of the entire program and discuss the positive outcomes experienced by $\mathrm{TK} \mathrm{ABA}$ in context

g. Mediate and facilitate relationships with institutions that are able to develop the achievement obtained by TK ABA

TK quality improvement activities through management training accreditation preparation and filling questionnaire / instrument was originally done not in isolation, but rather synergize one another. This is done in order to take a long time and place too much, and do not disrupt the activities of the institution. This training can be done in addition to weekdays, and its implementation in conjunction with the program activities of the institution. But upon consultation with, it is considered very important and needs to be, and then ask participants to do specifically with the special time for such training. Therefore, these activities using participatory pattern initially, then become active participatory pattern.

\section{Framework}

Through active participatory planning found problems relating to the management of the institution especially with regard to the preparation of accreditation and charging boring / instrument TK ABA accreditation. In principle, the management of the institution's management in preparation for accreditation and charging questionnaire / TK ABA accreditation instrument different from accreditation preparation and filling of other educational institutions. For it to do some actions as follows:

1. Mapping the problems and needs of TK related school management, accreditation preparation, and charging accreditation forms / instruments.
2. Identification of potential. The method used is a focus group discussion (FGD).

3. Determination of the institution group.

4. The formulation of strategies, programs, type of exercise is expected to come from the management of TK ABA itself and formulated by a team of servants.

In the mapping is done with methods and techniques:

a. Observation techniques and transects / visits, inter alia, by observing directly into the field and search for places to see firsthand the potential and activities that can be done.

b. In-depth interviews with all parties involved, such as the manager of kindergarten, kindergarten supervisors, MORA, student trustee. Interview theme of kindergarten management, related requirements, accreditation standards TK, opportunity, preparation, administration, and others.

c. Focus group discussions, involving the element manager of kindergarten, kindergarten supervisors, teachers, staff, team devotee, RA academics, and others.

d. Formulate the problem institutions, related with management, accreditation preparation, and charging accreditation forms / instruments.

5. Data source

Sources of primary data obtained from the management of kindergarten. While secondary data obtained from the information provided by the parties and institutions concerned. Associated with this program, information obtained from the Department of Education early childhood field, Supervisor, Organizational Leadership or management related to the PWA Dikdasmen Padang, the relevant institutions are Bustanul Athfal Teacher Association (IGABA) Padang, Head of TK ABA, and more.

6. Processing and analysis of data

The data is processed and analyzed using the techniques: a. The problem analysis and objective analysis. The analysis was conducted jointly with the community, functioning as facilitator's servant. b. Matrix analysis of participation and action plans together with the community. The process of data analysis and processing is done on the principle of active, participatory, partnership, network expansion. With discussions expected to realize the problems faced by the beneficiaries, until eventually can be formulated action to take.

\section{THEORETICAL STUDY}

Early Childhood Education (ECD) is a development effort aimed at children from birth up to the age of six years are accomplished by providing educational stimuli to help the growth and development of children's physical and spiritual that has the readiness to enter further education.

Before entering elementary school (SD), Early Childhood Education (ECD) is very important. ECCE is an 
education before entering primary education which is an early development that from birth to the age of six. ECD indirectly with children are given educational stimuli that growth and development of the physical and spiritual well. The application of focused education to the child's growth and physical development with fine and gross motor coordination. Also trained intellect as intellect, creativity, and emotional intelligence, and spiritual intelligence, emotional sociology in the formation of attitudes, as well as behavior and religion.

Organizing and facilitating a holistic early childhood have an impact on growth and development, both physical motoric; cognitive, language and social development is becoming more complete and better, so as to better prepare children (school readiness) to follow further education (Dwi Hastuti, IPB, 2010). The growth and development of children in the womb until the age of about 6 years will determine the level of health, intelligence, emotional maturity, and human productivity at a later stage. (Syarief Hidayat, 2002).

Thus the importance of early childhood education, government policies seen in various forms, such as in Indonesian ECD Development Strategy 2011 - 2025. Construction of ECD generally directed to the creation of integrated early childhood services. The main focus of the program leads to two main issues: first, expansion of access and equity, as well as both improving quality of service. Early childhood development strategy is generally pursued through various steps leading to the creation of integrated early childhood services. Through strategy integrated services in the form of early childhood education there are several benefits, among others: (1) an increase in efficiency through the use of integrated resources; (2) The quality of service is guaranteed because the manager has experienced (not new). (http://paudjateng.xahzgs.com/2015/03/strategipembangunan-paud-indonesia/ 13,112,016).

Beginning in 2011 is expected to be a milestone in the development of early childhood education in Indonesia. The measures that will be implemented through: 1) expansion and improvement of the quality of early childhood unit, 2) increasing the quantity and quality of early childhood PTK, 3) strengthening the role of parents and the community, and 4) strengthening and empowering partners (stakeholders, stakeholders). Therefore, to improve the quality of early childhood education, does the government have imposed accreditation. Accreditation is assessing the feasibility of a program of activities in the education unit based on the established criteria. Accreditation is done on the basis of criteria that are open. While the accreditation instrument used to obtain the data relating to eight (8) SNP that describes the objective conditions of early childhood. Therefore, This instrument should be completed by the manager of early childhood or parties responsible for the implementation of early childhood. Answers to questions and statements must be in accordance with the procedure established early childhood accreditation by BAN-PNF.

Accreditation is done to determine the feasibility of the program and / or units of education in formal education and non-formal at all levels and types of education. (Article 60 paragraph (1). Accreditation of programs and educational units by government and independent authorities or agencies as a form of public accountability. (Law N0. 20/2003 on the National Education System (Article 60 paragraph (2)

The ECD and PNF Accreditation aims to provide an assessment (assessment) in an objective, transparent, and sustainable access to the feasibility of a program and PNF based on criteria that have been set. While the implementation of the accreditation of programs and units of early childhood and PNF will benefit, among others:

1. Improve the vision, mission, goals, objectives, strategies, programs and PNF;

2. Improving the quality of early childhood programs and units of the PNF;

3. Utilizing all the information on the results of accreditation as feedback, in an effort to empower and develop the performance of programs and units of early childhood education and PNF;

4. Encouraging early childhood unit and PNF to keep working to improve the quality of programs and institutions gradually, planned, and competitive at the district / city, provincial, regional, national, and international event;

5. Obtaining information is reliable and accurate, in the framework of early childhood learning society and PNF,

6. Receive support in the form of guidance from the government and the appreciation of the public (http://web.banpnf.or.id/index.php/akreditasipnf/2014-06-27-09-02-23, Downloaded; 13102016)

1. Accountability, as a form of school / madrasah to the public, whether the service is rendered has met the expectations of society or not

2. Knowledge, as information to the public / public on the feasibility and performance of school / madrasah concerned

3. Coaching and development, i.e., as the basis for school / madrasah in an effort to improve their quality.

The mechanism of accreditation is:

1. Meet the requirements for accreditation

2. Knowing Stages of accreditation such as: application for accreditation, examination of the initial beam, desk assessment, visitation accreditation, validation and verification),

3. Assessment document and implementation

Thus, the importance of accreditation, clearly requires every manager needs to know, understand and skilled to do so, appropriate accreditation mechanism intended. Based on the above theory study, researchers / servant is called to perform the activities with a focus on the preparation of 
the charging instrument towards accreditation, in order to improve the quality of kindergarten institutions $\mathrm{ABA}$ in Padang.

\section{A. TK ABA Overview \\ 1. TK ABA Situation}

The location of activities is in the city of Padang, with the subject throughout the Kindergarten 'Aisyiyah Bustanul RA (TK ABA). Based on data from the Department of Education Padang 2016), TK in Padang amounted to 305 units. However, based on information directly with Mother Reny yudhia (Kasi early childhood Padang, dated October 3, 2016), under the Department of Education kindergartens in the city of Padang amounted to 275 units. That is, there are 30 units of kindergarten no longer active. In 2015, the new accredited about 19 units TK $(6.90 \%)$, including 2 of the number of 36 units of which TK ABA. This means that 256 units have not been accredited kindergarten (93.09\%). 2016 is the kindergarten is in the process of accreditation as much as +100 units and 2016 will go down in accreditation. As a general illustration can be seen as follows:

Table 1. Number of TK in Padang Year 2016-2017

\begin{tabular}{|l|l|l|l|l|}
\hline No & $\begin{array}{c}\text { Amount } \\
\text { TK }\end{array}$ & Accredited & $\begin{array}{c}\text { Not } \\
\text { accredited }\end{array}$ & Resources \\
\hline 1 & 39 units & 15 units & 24 units & MORA \\
\hline 2 & 36 units & 2 unit & 34 units & IGABA \\
\hline 3 & 275 units & 19 units & 256 units & DIKNAS \\
\hline 4 & 305 units & - & - & $\begin{array}{l}\text { ECD/web } \\
\text { diknas } \\
\text { Padang }\end{array}$ \\
\hline
\end{tabular}

In addition to the kindergarten under the auspices of Department of education and culture field of Early Childhood Education, there is also a kindergarten under the auspices of the Ministry of Religious Padang totaling 39 units. Based on information, which is already accredited 14 kindergartens $(29 \%)$, that is to say, there are 25 kindergartens $(71 \%)$ who have not been accredited. (MORA, madrassa education, Fitria, May 18, 2016).

The TK ABA in Padang totaled 36 units, two in antaraanya already going through the accreditation process. That is, in general TK ABA has not been accredited. The number of teachers 144 people, 24 of them are civil servants with the number of students 1,416 pesetas. Along the way, TK ABA has two organizations that shelter. Under the education department was named the Association of Kindergarten Teachers Indonesia (IGTKI), currently under Dikdasmen 'Aisyiyah shaded by an organization called the Association of Teachers' Aiyiyah Bustanul RA (IGABA) city level to the national level. However, TK ABA looks generally not terapkreditasi, because of knowledge, understanding and skills in terms of accreditation is still being dielajari, and in desperate need of guidance. Through search, ABA TK state information obtained in Padang [attached data].

Information through the Mothers Igaba (Association of Teachers Aisyiyah Bustanl RA), at monthly meetings, in kindergarten 'Aisyiyah I, St. Tarandam III Padang, Tuesday, October 4, 2016.

\section{Present condiition}

One form of education units within the framework of national education is the Kindergarten (TK). According to the government or the Regulation No. 27 of 1990, TK is one form of pre-school education. TK is not a prerequisite for entering primary education, but the presence of TK quality, is expected to help students in laying the basis towards the development of attitudes, knowledge, skills, and power goals that are necessary to adapt to the environment and for the growth and development The next child. Therefore, the management of these institutions in a professional manner should be applied in all kindergartens, which are integral with one another closely related and influence.

According to Habibullah Fuadi (Head of Education Department field), that Improving the quality of education is always expected of all walks of life in our country would have been the focus of human activity education in the city of Padang. The government of Padang always trying, with various methods of improving the quality of education, not only improvement of science and technology but also an increase in faith and devotion to God Almighty. This is in line with the strategic plan of the National Education programs, which include: 1) improving access to education, competence and competitiveness of the nation, 2) improving the quality and the quality of education, and 3) improving management and education services that are transparent, accountable and good governance. ((Http://www.diknas-padang.org/index.php/ images/sekolah\&op=sek\&kat=TK, 04,112,016).

The government in this case the education department or ministry of religion, constantly improve and develop education ranging from the most basic level of the kindergarten to college. This is evidenced by the early childhood education institutions in various lines.

The existence of TK ABA increasingly necessary in order to implement the values of faith which has become the main needs in early childhood education in early childhood institutions. Parents will feel lucky to sending their children to kindergarten ABA because it can ease parents in educating children as the next generation of the family. All institutions have a duty to improve the quality of education as the goal of education in the city of Padang in particular and the national education generally. In kindergarten is the most appropriate place to instill character values in accordance with the understanding of the Islamic faith since early. The public will be assisted in building the next generation in the struggle to create a society that is dignified. How exactly the current conditions TK ABA in Padang?

a. Poor management of the institution so that the accreditation preparation and charging instruments is constrained.

b. Society demands the quality of kindergarten, accreditation is very urgent to do, because TK ABA in Padang average yet accredited, 
c. TK ABA business has no experience related to knowledge, understanding and skills on how to prepare the accreditation and the charging instrument.

d. TKABA as a basic religious education institution which is a school that introduces the learning process, the formation of character, and the introduction of religious values in children. Therefore TKABA must be qualified institutions.

e. Weak TKABA management in preparation for accreditation and accreditation forms filling, so much needed assistance to the institution in the form of training for managers TKABA.

f. TKABA as an educational institution that is mostly owned by the community, it is necessary for their development of universities such as the Faculty Tarbiyah and Teaching IAIN IB in improving the quality of independent institutions.

4. The expected conditions

a. TK ABA is able to independently improve the quality of legal institutions, demonstrated by its accredited kindergarten, so that public confidence to enter their child into kindergarten ABA getting better.

b. TK $\mathrm{ABA}$ is able to increase and improve the management especially in the field of administration, so it will have an impact on teaching and learning activities, and learning objectives can be achieved with good students.

c. Expected TK ABA accreditation process and who are filling accreditation forms / instruments, can improve school administration so as to face visitation with maximum preparation. This will have an impact on the achievement of accreditation kindergarten with prediket A.

d. TK $\mathrm{ABA}$ is expected to increase the value of religious education in society, namely as a faithbased educational institutions viable and its quality is parallel with general education institutions of the same level.

\section{FINDING AND DISCUSSION}

1. Event overview

Based on the strategy that has been mentioned earlier, found problems relating to the management of the institution in particular with regard to the preparation of accreditation and questionnaire / instrument accreditation kindergarten 'Aisyiyah Bustanul RA (TK ABA) in Padang. In principle, the management of the institution's management in preparation for accreditation and charging questionnaire / TK accreditation instrument different from accreditation preparation and filling of other educational institutions. The activities are as follows:

a. Mapping the problems and needs of TK ABA as an educational institution management sekaitan accreditation preparation, and charging accreditation forms / instruments. Through observation and transect / visit, devotees observe directly into the field and search for places to see firsthand the potential and activities that can be done. Information is obtained as follows:

As for the kindergarten set as an object of devotion is TK ABA in Padang, amounting to 36 units, with the number of teachers $=144$, (PNS status as many as 24 people), the number of children of approximately 1,416 children.

By unraveling researcher/ stewards interviewed the manager, relevant knowledge, understanding and skills related to managing the preparation of the charging instrument management accreditation. Of the instrument, it was found that the problem as follows:

a. The lack of knowledge and understanding of the management of the requirements, the steps being taken and the charging instrument Accreditation TK ECD

b. The lack of knowledge and skills of managers in menpersiapkan document Accreditation instruments Kindergarten / Early Childhood Education (ECD)

c. The lack of knowledge and skills of managers about the charging instrument Accreditation Kindergarten / Early Childhood Education (ECD)

d. The lack of understanding and skills in preparing documents has become a manager of the charging instrument accreditation

e. The lack of understanding and skills of managers on the assessment rubric accreditation instrument Kindergarten / Early Childhood Education (ECD)

2. Determine priorities for action preparatory charging instrument management training accreditation, which is the capital of solving problems, and chances are very open. Training action is related to knowledge, understanding and skills manager of TK $\mathrm{ABA}$ as follows;

a. knowledge and understanding of the management of the requirements, steps that must be carried out and the charging instrument Accreditation TK ECD

b. knowledge and skills of managers in preparing documents Accreditation instruments Kindergarten / Early Childhood Education (ECD)

c. knowledge and skills of managers about the charging instrument Accreditation Kindergarten / Early Childhood Education (ECD)

d. understanding and skills in preparing documents has become a manager of the charging instrument accreditation

e. understanding and skills of the accreditation assessment rubric instrument Kindergarten / Early Childhood Education (ECD).

3. Identifying potential in order to determine what efforts have been made by TK ABA in school management in preparation for accreditation and charging accreditation forms / instruments. The 
method used is a focus group discussion (FGD), together with the chairman / board of the Association of Teachers' Aisyiyah Bustanul RA (IGABA), together with the chairman of the panel of Dikdasmen PWA and PDAs. The results obtained in the case are as follows;

a. ABA TK that managers have received training from the Education Department in the city of Padang as many as 5 people from the TK 36 units. With new knowledge and experiences through this training, the head of the kindergarten have tried to do the charging instrument of accreditation is that at this point in the process.

b. PWA that Dikdasmen Council and PDA Padang, has provided guidance on Accreditation Kindergarten / Early Childhood Education (ECD), which until now in the planning and will implement training or guidance on the issue of accreditation.

c. What requirements are much needed guidance, stage what to do, and how to prepare various forms of documents related both school board and related to the implementation of education and teaching. All this is very relevant standard 8 by 60 votes Accreditation instruments Kindergarten / Early Childhood Education (ECD).

d. Head or manager of TK ABA always try to fix the administrative fine, and me-arsipkannya. But managers need guidance on how to conduct or management Adiministrasi is good and right.

e. As an Islamic-based primary education institution, it takes guidance of Islamic sciences of the relevant institutions, in particular the assembly Dikdasmen, FTK as high prguruan Islam, especially related to the management of learning. Because somehow in this kindergarten, children are educated are taught to read, perform and so on, the material is related to Islam, such as starting the job by calling basmalah, and other thaiyibah sentences.

5. Setting the whole manager TK ABA in Padang became a trainee, plus the regional program Dikdasmen Council Regional Chairman 'Aisyiyah (PWA) and the province of West Sumatra Padang Dikdasmen PDAs, as Trustees of Basic Education secondary. Then the participants set as many as $\mathbf{5 0}$ people, including heads and teachers, or technical school. It is necessary for all the heads of TK ABA currently being groped for preparation, fill and prepare the instrument of accreditation.

4. Assign the program, the type of exercise that comes from the manager TK ABA itself and formulated by a team of researchers / servants.

a. Strategy / devotion conducted through an institutional approach by including the relevant institutions Dikdasmen Assembly as TK ABA Pembina, Head of Early Childhood Education (PAUDNI) West Sumatra province, as an institution builder and manager of the establishment of accreditation kindergarten, as well as areas of expertise UNP professor of early childhood education. Through such strategies, discovered their strengths, weaknesses, capabilities, can be linked financially and can be fulfilled.

b. Develop programs in the form of training by three competent resource persons in the field, as follows:

1) material; 1. "Charging Preparation Instruments Management TK", given by Dra.Nur Asni Abbas, MA, Chairman of West Sumatra Dikdasmen Council / Supervisory Dikdasmen MORA / assessor secondary basic education

2) Material 2. "Mechanical Completion Instruments Accreditation The Good And Right", given by Dra.Hj.Sumarni, M.Pd. (Tim), Head PUDNI West Sumatra

3) Material 3. "The existence of the TK-ABA Character Generation Against Establishment", given by Dr. Hj.Syur'aini, M.Pd. UNP faculty expertise ECD / assessor

c. Set the time and place of execution of training on October 22, 2016, at the Hall of the Office of Regional Board 'Aisyiyah West Sumatra, Jalan S. Parman No. 129 Padang Ulak Karang.

d. Carry out an evaluation by the manager of TK ABA, on October 4, 2016 through routine activities IGABA Padang, housed in TK ABA 01 road Terandam III Padang.

Filling Instruments Accreditation is the sole responsibility of the head of TK / RA. Charging Preparation Instruments Management TK is absolutely necessary for each head of TK, because a lot of things that need to be prepared and conducted and evaluated. As we know that the Technical Instructions (Juknis) Charging Instrument This accreditation provides explanations and detailed information about physical evidence, documents, or the fact that it must be shown by the TK ABA and obtained by the assessor at the time of visitation to answer each item statement on the Instruments of Accreditation.

Regulation of the Minister of Education and Culture on early childhood education and accreditation; Number: 1462014 Curriculum 2013 Early Childhood Education: One of the articles contains the following: "In Article 5 .... ECD curriculum structure contains development programs that include religious and moral values, physical, motor, cognitive, language, social emotional and art. No. 137 of 2013 on National Education Standards Childhood "In the standard content of article $10 \ldots$. Literacy includes the understanding of the relationship of shapes and letter sounds, mimicking the shape of the letter and understands the words in the story.

Among principal tasks and functions of the National Accreditation Board for Non-Formal Education (BAN-PNF) is carrying out the accreditation of Early Childhood Education (ECD). Accreditation is a feasibility assessment activity and their units PNF program based on the established criteria.

For assessing the feasibility of the structured instruments accreditation refers to the National 
Education Standards (NES) as determined by the Indonesian Government Regulation No. 32 of 2013 on the Amendment to the Indonesian Government Regulation No. 19 of 2005, which includes eight (8) standard, namely 1) Standard competency, 2) Content Standard, 3) Processing Standards, 4) Standards and Education Personnel, 5) Infrastructure Standards, 6) Standard Management, 7) Standard Funding and 8) Education Assessment Standards. Special early childhood, Graduate Competency Standards uses the term Standard Achievement Rate Developments (TPP). Accreditation instrument used to obtain the data relating to eight (8) SNP that describes the objective conditions of early childhood. Therefore, this instrument should be completed by the manager of early childhood or parties responsible for the implementation of early childhood. The answer to the question / statement must be in accordance with the procedures established early childhood accreditation by BAN-PNF. (INST-PAUD2014)

On the other hand, the management of a school requires good management. Management of professional school is absolutely necessary for the management and oversight, so that indicators of management activities that can be applied properly, optimized and all components of the system can be run in a planned, organized, directed, monitored, coordinated, controlled and evaluated both on effectiveness and in terms of efficiency. Mulyasa said, "Failure and success are determined by the school principal, because it is to control and determine the direction to be taken to the destination school." (Mulyasa, Being Principal Professionals in the Context of the success of the MBS and the CBC, (Bandung: PT Young Rosdakarya, 2003: 158).

Through the assistance carried out on the preparation of the accreditation TK-ECD filling of this, many things related to relate scientific obtain accreditation. Through the accreditation of an educational institution, the perceived benefits gained, leading a quality school and children's quality as well. Through accreditation, felt how important it was the responsibility of a manager in the eyes of people who give credence to, and on the other hand as his boss, who then later will lead everyone into account for all their deeds which refers to religious requirements. Through accreditation serves as a form of accountability, as knowledge, and as guidance and development, the more so perceived. (See: Study of theory chapter II)

Accreditation is a feasibility assessment activities and their units PNF program based on the established criteria. To assess the feasibility of structured instruments accreditation refers to the National Education Standards (NES) as determined by the Indonesian Government Regulation No. 32 of 2013 on the Amendment to the Indonesian Government Regulation No. 19 of 2005, which includes eight (8) standards. Eighth these standards is 1) Standard Competency, 2) Content Standard, 3) Processing Standards, 4) Standards and Education Personnel, 5) Infrastructure Standards, 6) Standard Management, 7) Standard Funding and 8) Standard Assessment of
Education, Special early childhood, Graduate Competency Standards uses the term Standard Achievement Rate Developments (TPP).

Facing Step Eleven School Accreditation

Basically, the preparation of the accreditation should be started four years earlier; however, many new schools are aware and prepared themselves after being notified of the UPA that the school had time to register for accreditation.

Such steps are as follows:

1. Make sure Schools father / mother enrolled in accreditation quota in 2016

2. Accreditation Preparation Team formed corroborated by the Decree of the Principal.

3. Downloading Instruments Accreditation for School Self-Evaluation (EDS).

4. Carry out the preparatory division of Accreditation meeting chaired by the principal. (Is the recommended inviting the school for the adviser supervisors gain advice and guidance).

5. Filling the instrument by a team jointly led by the Principal. Perform calculations estimate the acquisition value is in line with expectations considering the state of the question in the riel each item of the instrument.

6. Copying an instrument that has the contents as much as 3 copies.

7. Submit instrument which has the contents (2 copies) to the appointed place

8. While waiting for the visitation schedule (late April), the school may make improvements and complements the deficiencies of the physical evidence will be shown to the assessor when visitation to each question item.

9. Consult your supervisor to complete the physical evidence of each item in instrument. assessors who came to vitalize schools do not require a verbal response but rather the physical evidence.

10. If the day of visitation has been set school must undertake pro-active steps to receive visitation assessors for example offers a shuttle when school is located far from the road, providing a place to stay for a team of assessors assigned BAP-S / M Lampung and visitation two days.

11. Make sure that on the day of visitation all components of school teachers, principals, school committee present at the school and show that the school truly ready for the visitation, as well as to create awareness that this is an important event and it must be encouraged so that in later preparations must be made at least 4 years earlier.

http://korwastanggamus.blogspot.co.id/2016/0 3/sebelas-langkah-darurat-menghadapi.html

Step-by-step how to conduct early childhood accreditation easy enough but not as easy as the bureaucracy in the field, make sure the manager kindergarten graduation general and specific requirements 
of accreditation, complete the necessary paperwork for accreditation, and also of course have to filling instrument early childhood accreditation, So what should a manager do when it was collecting requirements are also already filling instrument TK-ECD accreditation? What to do with these documents? The manager will know the answer after seeing the accreditation mechanism ECD (TK RA KB TPA BA) conducted Accreditation ECD.

Related training in research / service is part of the 5 (five) of the steps, but to do this, closely related to the others steps. Therefore, it is perceived how knowledge learned related charging this instrument, because all school activities in question involve all management components of a school, for the success of a school and to the school grade or quality.

\section{CONCLUSION AND SUGGESTION}

Policies made by the government through the national Program Accreditation Board (BAN) whose job accredit the entire early childhood in Indonesia, including ECD-TK 'Aisyiyah for this accreditation reflects the quality of early childhood education in the city of Padang in particular and Indonesia in general. Based on the implementation of the study / service above is known that;

1. Accreditation is a form of quality assurance of education in Indonesia.

2. The quality of a school is not only influenced by the principal alone but an accumulation of various parties

3. Charging accreditation instrument for every manager TK ABA, should follow the steps to do the school in the face of implementation of accreditation

4. The steps do TK ABA / ECD in dealing with the implementation of accreditation when done well through good preparation will give good results

5. ABA TK-quality institutions are very helpful the success of the students to achieve success.

6. The existence of TK ABA qualified and recognized by the government and the public to go through the assessment or evaluation.

7. ABA qualified kindergarten wrong only to be accredited by the government.

Therefore, it is recommended;

a. The need for mentoring accreditation preparation continuously

b. TK ABA accreditation process and who are filling accreditation forms / instruments, can improve school administration so as to face visitation with maximum preparation. This will have an impact on the achievement of accreditation kindergarten with prediket $\mathrm{A}$.

c. TK ABA can increase the value of religious education in society, namely as a faith-based educational institutions viable and kualitasnnya parallel with general education institutions of the same level. d. The steps that must be passed by the manager of TK ABA in Padang related knowledge, understanding and skills in the charging instrument of accreditation can be overcome by continuing to follow the accreditation and other related training.

\section{REFERENCES}

[1] Arief, Armai, 2005. Reformulation of Islamic Education, Jakarta: CRSD Press.

[2] Bafadal, Ibrahim, 2003. The management Sari School-Based Education Quality Improvement, Quality Improvement Management Towards Primary School Of Centralized Decentralization, Jakarta: PT Earth Literacy.

[3] Depatemen Religion, RI., The Directorate General of Institutional Development of Islamic Studies, 2005. Insight Task Teachers and Education Personnel, Jakarta.

[4] Depatemen Religion, RI., 2004. Directorate General of Institutional Development of Islamic Studies, Islamic School Development Guidelines and Religious Education in 2004-2009, Jakarta.

[5] Hakim, Rosniati, Character Building Based Education of Students through the Koran, Character Education Journal, Year IV, No. 2, June 2014, Publisher: LPPM University of Yogyakarta. ISSN; 2089-5003.

[6] Hakim, Rosniati, (2019/1440). The Improvement of Students' Competence in Islamic Education Program through Tahsin Al-Quran Activities, Khalifa Journal of Islamic Education :: Volume 3, Number 1, March 2019 P-ISSN: 2541-6588; EISSN: $2549-4783$.

[7] Hakim, Rosniati, 2016.Islamic Pre-School Management and Its Implications towards Students' Learning Quality Improvement:Al-Ta lim Journal, e-ISSN 2355-7893. Volume 23, Number 2, Faculty of Islamic Education and Teacher Training State Islamic Institute Imam Bonjol Padang.

[8] Irawan, Prasetya, 1999. Logic and research procedures Jakarta: STIA-LAN Press.

[9] Mulyasa, 2003. Being a Principal Professionals in the Context of the success of the MBS and the CBC, (Bandung: PT Young Rosdakarya.

[10] Moeslichatoen, 2004. Teaching in Kindergarten, Jakarta: Rineka Copyright. 
[11] Nata, Abuddin, 2001. History of Growth and Development of Islamic Education Institutions in Indonesia, Jakarta: PT.Gramedia.

[12] Nata, Abuddin, 2011. Comprehensive Islamic Studies, Jakarta: Prenada Media Group.

[13] Nata, Abuddin, 2012. Capita Selecta Islamic Education, Jakarta: PT.Grafindo.

[14] National Education Minister Regulation No. 52 Year 2009 on Criteria and Accreditation Device Kindergarten / Raudhatul RA (TK/ RA).

[15] Pidarta, Made, 2004. Education Management Indonesia, Jakarta: PT. Rineka reserved.

[16] Rahim, Husni, 2001. New Directions Education Islam in Indonesia, Jakarta: Logos Discourse Studies.

[17] Raynolds, Larry J., 2005. Ways of School-Based Management A Guide for Practitioners Education, Interpretation: Teguh Budiharso, Jakarta: PT. Diva Reader.

[18] Rianingsih Djohani, 1996. Acting Together Acting Together: Reference Application of Participatory Rural Appraisal, Bandung: Studio Driya Media.

[19] Subhan, Arif, 2012. The Indonesian Institute of Islamic Education in the 20th Century, Jakarta: Dawn Interpretama.

[20] Syafaruddin, 2005. Management of the Institute of Islamic Education, Jakarta: Ciputat Press.

[21] Tafsir, Ahmad, 2008. Strategies to Improve Islamic Education, Bandung.

[22] Drafting Team CBR, 2015. Community-Based Reasearch, Surabaya: LP2M Sunan Ampel. 